\title{
Grain yield of Phaseolus vulgaris in a function of application of boron in soil
}

\author{
Rilner Alves Flores ${ }^{1 *}$, Raissa Alves Rodrigues ${ }^{1}$, Patrícia Pinheiro da Cunha ${ }^{2}$, Virgínia \\ Damin $^{1}$, Everton Martins Arruda ${ }^{1}$, Klaus de Oliveira Abdala ${ }^{3}$, Mayara Cardoso Donegá ${ }^{1}$ \\ ${ }^{1}$ Department of Soil Science. Agronomy School, Federal University of Goiás, Goiânia, GO, Brazil \\ ${ }^{2}$ Agriculture of Soil Science. Agronomy School, Federal University of Goiás, Goiânia, GO, Brazil. \\ ${ }^{3}$ Rural Development of Soil Science. Agronomy School, Federal University of Goiás, Goiânia, GO, Brazil. \\ *Corresponding author: rilner1@hotmail.com
}

\begin{abstract}
The objective of this study is to evaluate the effects of sources and doses of boron on the physiological quality and production yield of Phaseolus vulgaris grown using a central pivot irrigated system on a tropical climate region. The experiment was a $4 \times 5$ factorial design representing four sources of boron (boric acid, borax, borogran and FTE BR 12) and five boron doses $\left(0,1,2,3\right.$ and $\left.4 \mathrm{~kg} \mathrm{ha}^{-1}\right)$, with four replications. The following parameters were measured: relative chlorophyll index, transpiration, $\mathrm{CO}_{2}$ internal concentration, stomatal conductance, net photosynthesis, B content, grain yield and economic analysis. The relative chlorophyll index (RCI) of plants showed no significant effects at both 28 and 46 days after emergence (DAE). The extraction order of boron was boric acid $>$ borax $>$ FTE BR12 $>$ Borogran. The application of boron did not affect the physiological quality (stomatal conductance, transpiration and internal concentration of $\mathrm{CO}_{2}$ ). However, the net photosynthetic rate was lower when boric acid was applied in relation to other sources. The maximum production $\left(4,446 \mathrm{~kg} \mathrm{ha}^{-1}\right)$ was obtained using $1.35 \mathrm{~kg} \mathrm{ha}^{-1}$ of B with the use of boric acid. However, according to an evaluation of economic viability, it is observed that there are economic differences among sources of boron and evaluated doses. The application of $4 \mathrm{~kg} \mathrm{ha}^{-1}$ of borax provides the highest economic return.
\end{abstract}

Keywords: Plant nutrition, micronutrients, economic viability, physiological quality, photosynthesis

\section{Introduction}

Common beans (Phaseolus vulgaris L.) is a basic food, with a high socio-economic importance to Brazil (Richetti et al., 2013). Brazil is second largest world producer of bean grains, following
India (FAO, 2012). The importance of bean grain production is because this food is part of several food security programs of developing countries (Embrapa, 2012). 
However, in production systems aiming high productivities, a proper management of mineral fertilization programs required to maintain the nutritional balance of plants is essential. Regarding fertilization, although required in smaller quantities, micronutrients are very important for the growth, development and production of dry beans. However, with regard to their fertilization recommendation, they are still incipient (Couto Júnior et al., 2013). Among micronutrients, boron (B) has a narrow range of suitable contents and toxic contents in the soil solution. This evidences the need for further calibration of its supply via fertilization management (Trautmann et al., 2014). Among micronutrients, the low natural boron content in the soil has been a limiting factor for the production of common bean grains in Brazilian tropical regions (Mattiello et al., 2009; Euba Neto et al., 2014). Its availability is mainly influenced by soil pH values (Sá and Ernani, 2016), soil organic matter (Lima et al., 2007), mobility in the soil profile (leaching) due to the high intensity of rainfalls (Prado, 2008), soil parental material, topography and soil type and use (Zhu et al., 2016).

$\mathrm{B}$ is essential to many plant physiological processes such as transport of sugars, cell wall synthesis, lignification, cell wall structure, carbohydrate metabolism, RNA metabolism, respiration, IAA metabolism, phenolic metabolism, ascorbate metabolism, germination and pollen tube growth. It is also related to the integrity of the plasma membrane (Malavolta, 2006; Dechen and Nachtigall, 2006; Prado, 2008; Marschner, 2012). Moreover, B is related with physiological activity in crops, which may block the chlorophyll synthesis and, as a consequence, the photosynthetic activity in plants with B deficiency (Yadegari. 2016). According with Wasaya et al. (2017), plants with adequate B levels are more tolerant to abiotic stress.
The cultivation of common beans using irrigated systems is the subject of great attention because of potential losses of B by leaching in Brazilian tropical soils, especially where there are textures from medium to sandy ( $<35 \%$ clay) (Prado, 2008). Flores et al. (2017) observed that B application rates up to $4 \mathrm{~kg}^{-}$ ${ }^{1}$, using borax as a B source, can increase grain yield with a positive economical budget. Thus, studies on these environments involving boron and bean crops are important for a better understanding of fertilization management. In this sense, studies on the use of sources and doses containing boron in such regions may contribute to a sustainable grain production, avoiding losses of B and preserving environmental resources. Thus, the objective of this study was to evaluate the effects of sources and doses of boron on the physiological quality and production yield of common beans grown in a central pivot irrigated system on a tropical climate region.

\section{Material and Methods}

\subsection{Growing conditions}

An experiment was carried out at Federal University of Goiás, Goiania, Brazil ( $16^{\circ} 35^{\prime}$ ' latitude south and $49^{\circ}$ $21^{\prime}$ longitude west, at approximately $730 \mathrm{~m}$ of altitude and $1,600 \mathrm{~mm}$ average annual rainfall), in an area with central pivot irrigation system. The climate is Aw (mega thermal) or tropical savannah, with dry winters and rainy summers, according to Köppen classification. The soil analysis showed the following properties: $\mathrm{pH}$ $\left(\mathrm{CaCl}_{2}\right)=5.1$; organic matter $=29 \mathrm{~g} \mathrm{dm}^{-3} ; \mathrm{P}=6.7 \mathrm{mg}$ $\mathrm{dm}^{-3} ; \mathrm{K}=0.52 \mathrm{cmol}_{\mathrm{c}} \mathrm{dm}^{-3} ; \mathrm{Ca}=1.7 \mathrm{mmol}_{\mathrm{c}} \mathrm{dm}^{-3} ; \mathrm{Mg}$ $=0.6 \mathrm{mmol}_{\mathrm{c}} \mathrm{dm}^{-3} ; \mathrm{S}=1.2 \mathrm{mg} \mathrm{dm}^{-3} ; \mathrm{B}=0.19 \mathrm{mg} \mathrm{dm}^{-3}$; $\mathrm{Cu}=2.8 \mathrm{mg} \mathrm{dm}^{-3} ; \mathrm{Fe}=82 \mathrm{mg} \mathrm{dm}^{-3} ; \mathrm{Mn}=44 \mathrm{mg} \mathrm{dm}^{-}$ 3; $\mathrm{Zn}=4.6 \mathrm{mg} \mathrm{dm}^{-3} ; \mathrm{H}+\mathrm{Al}=2.4 \mathrm{mmol}_{\mathrm{c}} \mathrm{dm}^{-3}$; cation exchange capacity $(\mathrm{CEC})=52.2 \mathrm{mmol}_{\mathrm{c}} \mathrm{dm}^{-3}$; base saturation $(\mathrm{V} \%)=54 \%$, with $420 \mathrm{~g} \mathrm{~kg}^{-1}$ of clay. 


\subsection{Treatments and experimental design}

The experimental units were five rows containing bean plants spaced $0.45 \mathrm{~m}$ apart, $5 \mathrm{~m}$ long, forming a total area of $11.25 \mathrm{~m}^{2}$. The two central rows were considered as floor area, and $0.5 \mathrm{~m}$ in length were discarded, totaling $3.6 \mathrm{~m}^{2}$. The experiment was randomized blocks (RBD) in a 4 x 5 factorial design representing four sources containing boron applied to the soil at planting (borax - 10\%, boric acid - 17\%, borogran $-10 \%$, and FTE (fritted trace elements) BR $12-1.8 \%$ ) at five doses: 0 (control), 1, 2, 3 and 4 $\mathrm{kg} \mathrm{ha}^{-1}$, with four replications. Soil was classified as Rhodic Hapludox (Soil Taxonomy, 2006).

\subsection{Treatments application and analysis}

The implementation of the research took place on June 23, 2015, using a central pivot irrigation system. On this occasion, acidity correction was performed using $310 \mathrm{~kg} \mathrm{ha}^{-1}$ of limestone (92\% Relative Total Neutralization Power (RTNP)) to increase soil base saturation to $65 \%$. After that, the soil was prepared with a plow and a corrective grid for the incorporation of acidity correction.

The sowing of common beans, cultivar BRS Estilo, was carried out in a spacing of $0.45 \mathrm{~m}$ between rows, 17 seeds per meter. The fertilization in furrows was $20 \mathrm{~kg} \mathrm{ha}^{-1}$ of $\mathrm{N}, 120 \mathrm{~kg}$ of $\mathrm{P}_{2} \mathrm{O}_{5}$ and $60 \mathrm{~kg} \mathrm{ha}^{-1}$ of $\mathrm{K}_{2} \mathrm{O}$ in the form of urea, simple superphosphate and potassium chloride, respectively. Cover fertilization was performed at 20 and 40 days after germination with 80 and $40 \mathrm{~kg} \mathrm{ha}^{-1}$ of $\mathrm{N}$ as urea, respectively (Sousa and Lobato, 2004).

\subsection{Physiological parameters}

The physiological parameters measured were: transpiration rate $(\mathrm{T})\left(\mathrm{mmol} \mathrm{m}^{2} \mathrm{~s}^{-1}\right)$, stomatal conductance $(\mathrm{gs})\left(\mathrm{mmol} \mathrm{m}^{2} \mathrm{~s}^{-1}\right), \mathrm{CO}_{2}$ internal concentration (Ci) ( $\mathrm{ppm}$ ) and net photosynthesis $\left(\mu \mathrm{mol} \mathrm{m} \mathrm{s}^{2}\right)$. These measurements were taken at R5 stage (between pre-flowering and pods formation), using an Infrared Gas Analyzer (IRGA, Li-COR, Lincoln, USA). Inside the plot, plants were chosen in a randomized pattern, and the first completely expanded leaf from the apex of the main stem was used. The measurements were performed between 9:00 $\mathrm{h}$ and 14:00 $\mathrm{h}$.

The relative chlorophyll index (RCI) was determined at 28 and 46 DAE (days after emergence), using a chlorophyll meter, model ClorofiLOG. In each plot, plants were taken in a randomized pattern, and the first completely expanded leaf from the apex of the main stem was used.

The foliar B level was evaluated in the preflowering stage. Samples were taken from 20 plants in each plot, using the diagnostic leaves (first leaf completely expanded), as recommended by Souza et al. (2011). Boron analyses were performed as described by Bataglia et al. (1983).

In each plot, $2 \mathrm{~m}$ of the three central lines were harvested in $5^{\text {th }}$ of October 2015. The plant's material was weighed and sub-sampled to determine grain yield $\left(\mathrm{kg} \mathrm{ha}^{-1}\right)$.

\subsection{Economic analysis}

The economic analysis was done using the partial budget technique (Noronha, 1987). The differential profit was calculated using the budget costs and the differential income, using the control treatment as a reference. Grain productivity was used to calculate the productivity gain in $\mathrm{B}$ treatments related to the control (PG). The production value (PV) was obtained by the following Equation 1: 
$\mathrm{PV}=\mathrm{PG}^{*} \mathrm{P}$

Equation 1

Were:

$\mathrm{P}=$ product price in Brazil. The average price deflated of the US\$ kg-1 0.81 (Agrolink 2016) was used, this value was calculated using data of price from the last 15 years (2001 up to 2016).

The differential profit was obtained by the following Equation 2:

$\mathrm{Pd}=\mathrm{Id}-\mathrm{Cd}$

Equation 2

Were:

$\mathrm{Pd}=$ differential profit

$\mathrm{Id}=$ differential Income $=\mathrm{Iti}-\mathrm{It}_{0}$

$\mathrm{Cd}=$ differential cost $=\mathrm{Cti}-\mathrm{Ct}_{0}$

$\mathrm{ti}=$ Treatment $\mathrm{i}$

$\mathrm{t}_{0}=$ Control

\subsection{Statistical analysis}

The statistical analyses were performed in a factorial scheme with two factors: B sources and B doses. When was observed significant interaction between the factors, the interactions were partitioned and the separated effect of each factor was not considered. Using the Sisvar programme, Brazil (Ferreira, 2014) the B source effect was evaluated using the Tukey's test $(p \leq 0.05)$ and the $\mathrm{B}$ doses effect was described using a regression analysis. The parameters used to choose the regression model were the $\mathrm{F}$ test significance, predict and adjusted $\mathrm{R}^{2}$ and the residual plots independence (including Durbin-Watson test for verify correlation between adjacent residuals).

\section{Results}

\subsection{Relative chlorophyll index (RCI) and boron content}

Regardless of the sources and doses of boron (B) applied to the soil, the relative chlorophyll index (RCI) of plants showed no significant effects $(p>0.05)$ both at 28 and 46 days after emergence (DAE) (Table 1). The average values for RCI were 36.46 and 38.18 $\mu \mathrm{g} \mathrm{cm}^{-2}$ at 28 and $46 \mathrm{DAE}$, respectively, regardless of the boron source and dose applied (Table 1).

Table 1. Relative chlorophyll index (RCI), B amounts in leaves, and grain yield of Phaseolus vulgaris in function of sources and increasing boron rates in soil.

\begin{tabular}{lcccc}
\hline Treatments & \multicolumn{1}{c}{$\mathrm{RCI}^{1}$} & \multicolumn{1}{c}{$\mathrm{RCI}^{2}$} & $\mathrm{~B}-\mathrm{leaf}$ & Grain yield \\
\hline Sources (S) & $-1-----\mu \mathrm{g} \mathrm{cm}^{-2}------$ & $\mathrm{mg} \mathrm{kg}^{-1}$ & $\mathrm{~kg} \mathrm{ha}^{-1}$ \\
Borax & $35.84 \mathrm{a}$ & $37.40 \mathrm{a}$ & $53.61 \mathrm{ab}$ & $4181 \mathrm{~b}$ \\
Boric acid & $37.43 \mathrm{a}$ & $38.84 \mathrm{a}$ & $55.62 \mathrm{a}$ & $4319 \mathrm{a}$ \\
Borogran & $36.68 \mathrm{a}$ & $38.62 \mathrm{a}$ & $48.45 \mathrm{~b}$ & $3934 \mathrm{c}$ \\
FTE BR 12 & $35.89 \mathrm{a}$ & $37.88 \mathrm{a}$ & $52.61 \mathrm{ab}$ & $4151 \mathrm{~b}$ \\
F & $1.06^{\mathrm{ns}}$ & $0.93^{\mathrm{ns}}$ & $3.34^{*}$ & $32.32^{* *}$ \\
Rates (R) $\left(\mathrm{kg} \mathrm{ha}^{-1}\right)$ & & & & \\
0 & 35.56 & 36.73 & 38.57 & 4027 \\
1 & 36.06 & 39.77 & 44.70 & 4169 \\
2 & 35.96 & 37.43 & 53.55 & 4231 \\
3 & 36.91 & 38.98 & 60.48 & 4170 \\
4 & 37.80 & 38.01 & 65.57 & 4140 \\
F & $1.20^{\mathrm{ns}}$ & $2.45^{\mathrm{ns}}$ & $35.95^{* *}$ & $5.65^{* *}$ \\
S x R & $0.70^{\mathrm{ns}}$ & $0.86^{\mathrm{ns}}$ & $1.50^{\mathrm{ns}}$ & $32.43^{* *}$ \\
C.V. & 7.78 & 6.99 & 12.17 & 2.62 \\
\hline
\end{tabular}

Means followed by the same letter in the column do not differ from each other by the Tukey test at 5\% probability. C.V. Coefficient of variation. ${ }^{1}$ and ${ }^{2}$ - at 28 and 46 days after germination, respectively. **, * and ${ }^{\text {ns }}$ significant at 1 and $5 \%$ and not significant at $5 \%$ of probability by the $\mathrm{F}$ test, respectively. 
Boron absorption by bean crops was affected in function of the source applied to the soil. The extraction order was boric acid $>$ borax $>$ FTE BR12 $>$ Borogran, with average contents of 55.62, 53.61, 52.61 and $48.45 \mathrm{mg} \mathrm{kg}^{-1}$, respectively (Table 1). The highest absorption of boron, when boric acid was applied, reflected in an increased productivity of the culture regardless of the dose applied (Table 1).

When performing polynomial regression analysis for the effects of doses on boron contents in leaves, it was noted that the absorption of B by the culture showed a similar behavior: all had a significant linear adjustment, i.e., leaf boron content increased with a greater supply thereof in the soil (Figure 1). The increases in leaf B contents were 118, 49, 76 and 56\% using borax, boric acid, borogran and FTE BR12, respectively, with application of the maximum dose $\left(4 \mathrm{~kg} \mathrm{ha}^{-1}\right)$ in relation to the control treatment (no application of B).

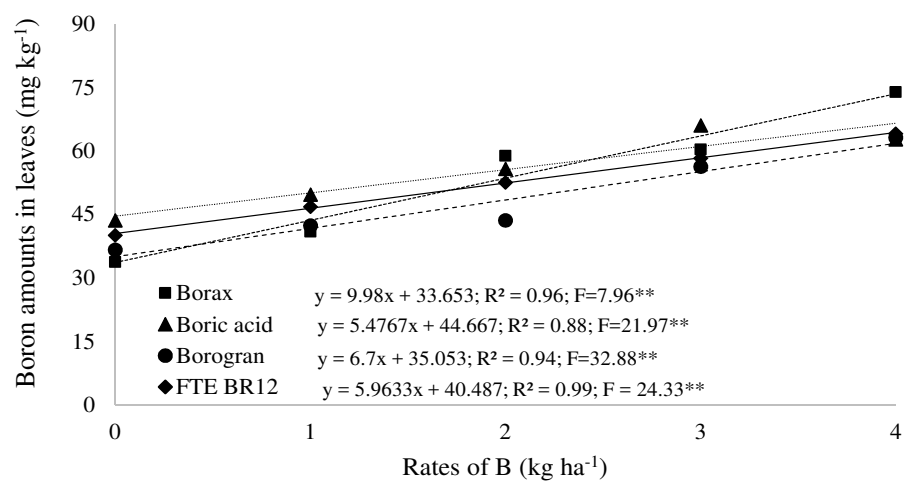

Figure 1. Boron amounts in leaves of Phaseolus vulgaris in function of sources and increasing boron doses in soil. ** - significant at $1 \%$ of probability by the $\mathrm{F}$ test.

\subsection{Grain yield}

The application of boron as boric acid promoted the highest grain yield when compared to the other sources regardless of the dose applied to the soil (Table 1). The highest yields were obtained using boric acid. The maximum grain yield $(4,444 \mathrm{~kg}$ ha ${ }^{1}$ ) was obtained using $1.35 \mathrm{~kg} \mathrm{ha}^{-1}$ of B (Figure 2).
Similarly, grain yield, when borogran was applied, presented a quadratic behavior. The maximum production $\left(4,249 \mathrm{~kg} \mathrm{ha}^{-1}\right)$ was obtained by using 1.15 $\mathrm{kg} \mathrm{ha}^{-1}$ of B. However, for borax and FTE $12 \mathrm{BR}$, the significant adjustment was linear, i.e., the highest yields $\left(4,649\right.$ and 4,393 $\left.\mathrm{kg} \mathrm{ha}^{-1}\right)$ were obtained using the highest dose, $4 \mathrm{~kg} \mathrm{ha}^{-1}$ (Figure 2). 


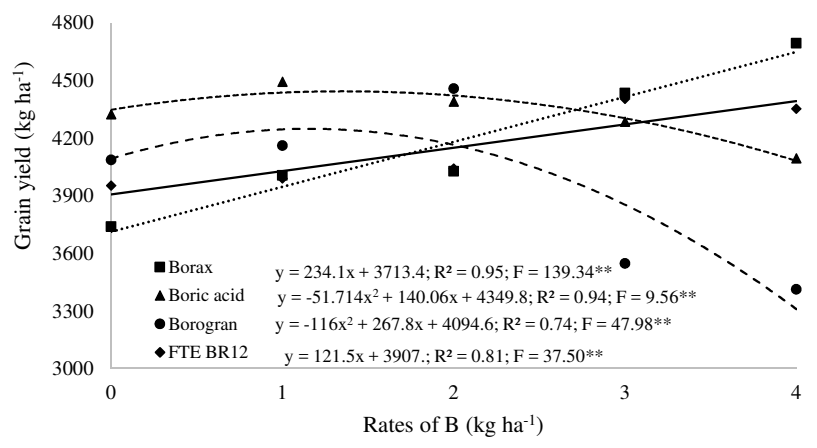

Figure 2. Grain yield of Phaseolus vulgaris in function of sources and increasing boron doses in soil. ** significant at $1 \%$ of probability by the $\mathrm{F}$ test.

\subsection{Physiological parameters and economic analyses}

The application of boron did not affect the physiological quality (stomatal conductance, transpiration and internal concentration of $\mathrm{CO}_{2}$ ) of bean plants in function of the source applied regardless of the dose applied to the soil (Table 2). However, the net photosynthetic rate was lower when boric acid was applied in relation to other sources (Table 2). The physiological quality (net photosynthesis rate and stomatal conductance) was influenced by the increase in the supply of boron into the soil independent from the source applied (Table 2). There was an increase in stomatal conductance amounting to 560, 588 and $493 \mathrm{mmol} \mathrm{m}^{2} \mathrm{~s}^{-1}$ using 2.33, 1.96 and $2.34 \mathrm{~kg} \mathrm{ha}^{-1}$, respectively (Figure 3).

Table 2. Physiological variables of Phaseolus vulgaris in function of sources and increasing boron rates in soil.

\begin{tabular}{|c|c|c|c|c|}
\hline Treatments & $\begin{array}{c}\text { Stomatal } \\
\text { conductance }\end{array}$ & $\begin{array}{c}\text { Liquid } \\
\text { photosynthesis }\end{array}$ & Transpiration & $\begin{array}{c}\text { Internal } \\
\text { concentration }\end{array}$ \\
\hline Sources (S) & $\mathrm{mmol} \mathrm{m} \mathrm{s}^{-1}$ & $\mu \mathrm{mol} \mathrm{m} \mathrm{s}^{2} \mathrm{~s}^{-1}$ & $\mathrm{mmol} \mathrm{m}^{2} \mathrm{~s}^{-1}$ & ppm \\
\hline Borax & $423.00 \mathrm{a}$ & $5.34 \mathrm{ab}$ & $0.79 \mathrm{a}$ & $396.23 a$ \\
\hline Boric acid & $449.40 \mathrm{a}$ & $4.96 \mathrm{~b}$ & $0.79 \mathrm{a}$ & $398.04 \mathrm{a}$ \\
\hline Borogran & $445.03 \mathrm{a}$ & $5.56 \mathrm{a}$ & $0.81 \mathrm{a}$ & $394.61 \mathrm{a}$ \\
\hline FTE BR 12 & $429.41 \mathrm{a}$ & $5.53 \mathrm{a}$ & $0.80 \mathrm{a}$ & $396.24 a$ \\
\hline $\mathrm{F}$ & $2.77^{\mathrm{ns}}$ & $5.54 * *$ & $0.14^{\mathrm{ns}}$ & $0.17^{\mathrm{ns}}$ \\
\hline \multicolumn{5}{|c|}{ Rates (R) $\left(\mathrm{kg} \mathrm{ha}^{-1}\right)$} \\
\hline 0 & 294.63 & 4.17 & 0.78 & 404.80 \\
\hline 2 & 451.65 & 5.49 & 0.81 & 397.85 \\
\hline 4 & 511.15 & 5.68 & 0.80 & 390.23 \\
\hline 6 & 526.58 & 6.04 & 0.86 & 395.59 \\
\hline 8 & 399.54 & 5.31 & 0.76 & 392.92 \\
\hline $\mathrm{F}$ & $125.04 * *$ & $29.98 * *$ & $2.56^{\mathrm{ns}}$ & $2.21^{\mathrm{ns}}$ \\
\hline$S \times R$ & $27.40 * *$ & $28.78 * *$ & $2.25^{\mathrm{ns}}$ & $2.02 *$ \\
\hline C.V. & 6.67 & 8.38 & 10.42 & 3.27 \\
\hline
\end{tabular}

Means followed by the same letter in the column do not differ from each other by the Tukey test at 5\% probability. C.V. Coefficient of variation. $* *, *$ and ${ }^{\mathrm{ns}}$ significant at 1 and $5 \%$ and not significant at $5 \%$ of probability by the $\mathrm{F}$ test, respectively. 


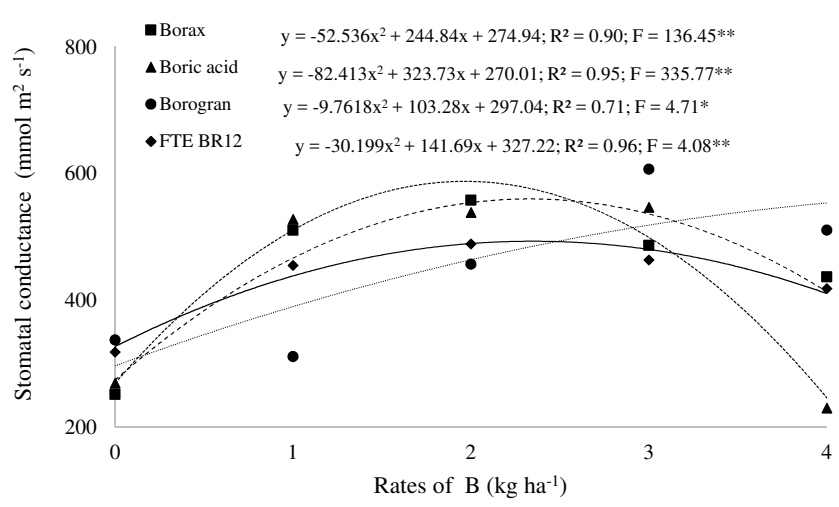

Figure 3. Stomatal conductance of Phaseolus vulgaris in function of sources and increasing boron doses in soil. ** and * - significant at 1 and $5 \%$ of probability by the $\mathrm{F}$ test, respectively.

Net photosynthesis rate had the same behavior with respect to stomatal conductance, i.e., quadratic increases in function of $\mathrm{B}$ doses applied to the soil (Figure 4), with the exception of borogran, which was not significant. Thus, the photosynthetic rate increased up to doses of $1.97,4$ and $1.95 \mathrm{~kg} \mathrm{ha}^{-1}$,

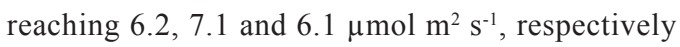
(Figure 4).

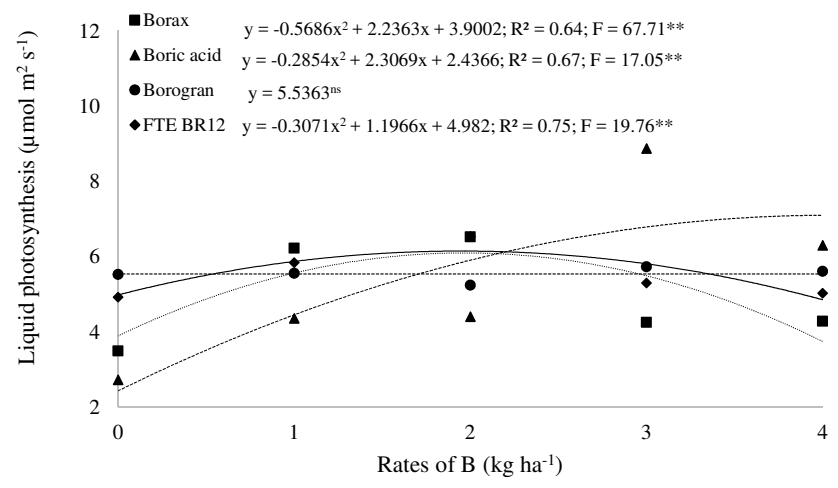

Figure 4. Liquid photosynthesis of Phaseolus vulgaris in function of sources and increasing boron doses in soil. ** and ${ }^{\mathrm{ns}}$ - significant at $1 \%$ and not significant at $5 \%$ of probability by the $\mathrm{F}$ test, respectively.

When evaluating the internal concentration of $\mathrm{CO}_{2}$, there was a significant adjustment only for boric acid, which decreased by using a high supply of boron, reaching $375.71 \mathrm{ppm}$, i.e., $10 \%$ lower when compared to the control treatment (Figure 5). 


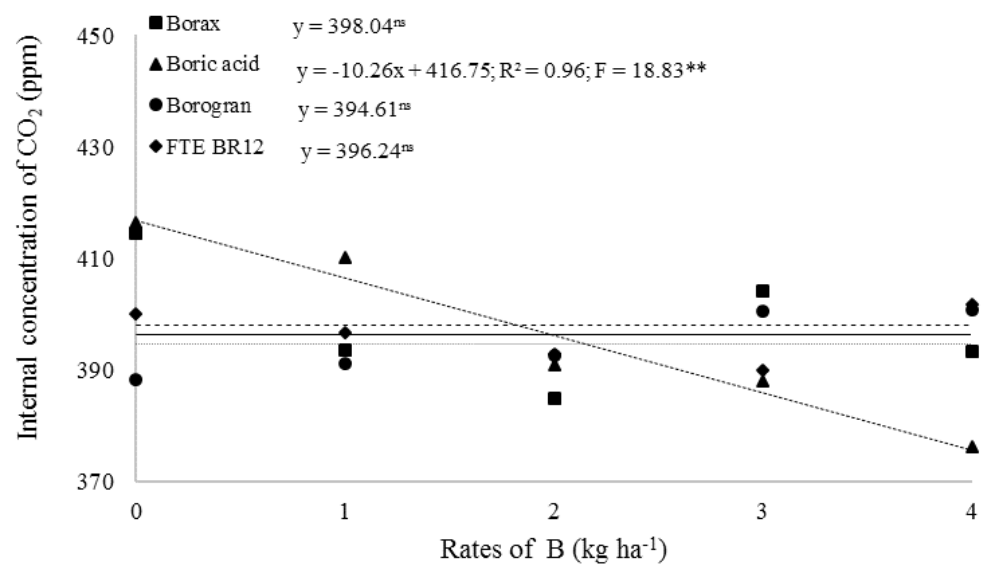

Figure 5. Internal concentration of $\mathrm{CO}_{2}$ of Phaseolus vulgaris in function of sources and increasing boron doses in soil. ** and ${ }^{*}$ - significant at 1 and $5 \%$ of probability by the $\mathrm{F}$ test, respectively.

When performing the analysis of economic viability in function of applied treatments, it was observed that all doses provided positive differential yields for the sources FTE BR12 and borax. The latter was economically more efficient than the other sources at all doses, except for the dose $2 \mathrm{~kg} \mathrm{ha}^{-1}$ of boron in relation to borogran. This can be explained because, at that dose, borogran provided the maximum technical yield (Figure 6). The dose of borax was still at increasing marginal yields.

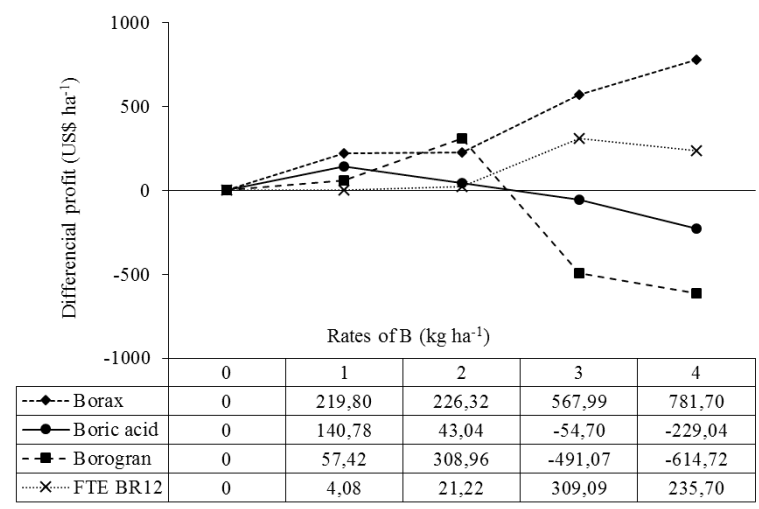

Figure 6. Differencial profit of Phaseolus vulgaris in function of sources and increasing boron doses in soil. 
The doses 1 and $2 \mathrm{~kg} \mathrm{ha}^{-1}$ of boron provided positive differential yields for all sources at the price level established in this study, indicating that the application of boron, under such conditions, is economically advantageous for the producer regardless of the source.

The sources boric acid, borogran and FTE BR12 showed decreasing differential yields from the doses 1,2 and $3 \mathrm{~kg} \mathrm{ha}^{-1}$, respectively, indicating that they are the most economically efficient doses for each source. The source borax had the highest positive differential gain: US\$ 781.70 per hectare at a dose of $4 \mathrm{~kg} \mathrm{ha}^{-1}$ of boron among all sources (Figure 6). However, it is noteworthy that the experiment was conducted under controlled conditions and uncontrolled factors such as drought or attacks by pests and diseases may affect the results.

\section{Discussion}

\subsection{Relative chlorophyll index (RCI) and B content}

The evaluation of RCI in function of soil boron application is justified by the fact that boron is related to the nitrogen assimilation process $(\mathrm{N})$ by plants (Ouzounidou et al., 2013). This is because boron can optimize the synthesis of nucleic acids and proteins, increasing photosynthetic activity and carbohydrate metabolism (Malavolta, 2006). The relative chlorophyll index (RCI) is based on the intensity of the green color in leaves, which is indirectly related to the chlorophyll content and, consequently, to the $\mathrm{N}$ content of the plant tissue (Godoy et al., 2008). Thus, boron deficiency in plants causes accumulation of $\mathrm{N}$-amino acids in relation to $\mathrm{N}$-proteins mainly due to the action of boron in the synthesis of nucleic acids, thus affecting plant nitrogen metabolism (Prado, 2008). Wasaya etal. (2017) also observed increases in chlorophyll content following B application, which increases in grain yield. However, Flores et al. (2017) studing the B effect in commun beans did not observe increases in chlorophyll content.

It is important to note that, upon the application of larger doses of boron, B contents in common bean leaves were above those considered suitable (30 to $50 \mathrm{mg} \mathrm{kg}^{-1}$ ) for cultivation in the region (Dechen and Nachtigall, 2006).

The boron mobility in the soil is high. The ion-root contact process is made through mass flow, following the transpiration stream until achieving plant shoots (Dechen and Nachtigall, 2006), factors that favor the nutrient absorption process by the culture (Mattiello et al., 2009). However, after the absorption and transport process via xylem, boron has a limited redistribution (via phloem), which favors a greater accumulation of complexed B on the cell wall (Prado, 2008; Marschner, 2012), providing high levels of B in diagnostic leaves suitable for the assessment of nutritional status.

During the cycle, the highest boron doses applied favored the appearance of some typical symptoms of toxicity such as shriveling and burning of old leaves. This symptom is typical when there is an excess of boron in plants, which may advance to chlorosis and necrosis at the edges and tips of older leaves (Trautmann et al., 2014), coinciding with the region where there is a greater transpiration and nutrient accumulation (Lemiska et al., 2014). This behavior was also observed by Flores et al. (2017) with foliar doses higher than $4 \mathrm{~kg} \mathrm{ha}^{-1}$ of $\mathrm{B}$.

\subsection{Grain yield}

This may be related to the high solubility of this source, since boric acid $\left(\mathrm{H}_{3} \mathrm{BO}_{3}\right)$ is in the form of crystals with a B content ranging between 17 and 18\% (Trautmann et al., 2014). In this case, the high solubility by this source promotes a fast release of boron into the soil solution, thus favoring its absorption by the root 
system via mass flow (Dechen and Nachtigall, 2006; Mattiello et al., 2009), especially in irrigated systems. The production of bean grains decreased when doses greater than $1.5 \mathrm{~kg} \mathrm{ha}^{-1}$ were applied using boric acid and borogran as source. This behavior may have occurred mainly due to the phytotoxic effect of the soil along the furrow, thereby reducing the potential for seed germination (Lima et al., 2013) and the growth of the root system (Trautmann et al., 2014). Still, its excess in the cell groove may decrease the photosynthetic rate (Chen et al., 2012), interfering with enzyme activity and affecting the synthesis of chloroplasts and electron transport capacity (Simon et al., 2013). Flores et al. (2017) also observed some phytotoxic effects of B when it was applied in doses higher than $4 \mathrm{~kg} \mathrm{ha}^{-1}$, using boric acid as a source. These authors evaluated B doses up to $8 \mathrm{~kg} \mathrm{ha}^{-1}$.

Some boron fertilizers have a high solubility, which may favor their mobility in the soil profile and thus promote greater leaching rates, especially in sandy soils (Trautmann et al., 2014). However, the application of boric acid (a preferable form absorbed by the culture) and clayey soils favor their absorption by plants and may thus reduce nutrient leaching rates (Dechen and Nachtigall, 2006; Prado, 2008). Thus, fertilization with boron aiming a high productivity, under the study conditions and using boric acid, may reduce the recommended dose by $25 \%$ without causing injuries to grain yield.

The increase in the grain yield of common beans in function of boron fertilization is due to the functions performed by the nutrient in the plant such as germination of pollen, pollen tube growth and seed formation (Dechen and Nachtigall, 2006; Prado, 2008; Marschner, 2012; Fageria et al., 2015). Thus, it becomes evident that an adequate supply of B via soil, both by the source and the dose at fertilization, may improve the nutritional balance of $\mathrm{B}$ in common bean plants and positively influence grain yield.

\subsection{Physiological parameters and economic analyses}

It can be observed that the increase in leaf $\mathrm{B}$, when boric acid (Figure 1) was applied, caused a decrease in net photosynthetic rates (Table 2) mainly by reducing the synthesis of sugars (Simón et al., 2013). It caused damages to the structures of thylakoids (Papadakis et al., 2004), affecting chloroplasts and electron transport capacity (Simon et al., 2013). The same behaviour was observed by Flores et al. (2017), since foliar application of B, using B doses up to 4 $\mathrm{kg} \mathrm{ha}^{-1}$ (borax) also affected the photosynthetic rates in common beans. However, using boric acid as a source, a linear increase in photosynthetic rates was observed using B doses up to $8 \mathrm{~kg} \mathrm{ha}^{-1}$.

According to Silva (2007), an excessive fertilization using B may promote increases in the concentration of $\mathrm{B}$ in the cytoplasm. It increases the formation of complexes with $\mathrm{NAD}^{+}$, directly affecting the photosynthetic process. Still, it may interfere with the absorption and metabolism of cations, especially $\mathrm{Ca}$ cations, and water absorption by plants (Dechen and Nachtigall, 2007).

This reduction in the internal concentration of $\mathrm{CO}_{2}$ is directly related to the low photosynthetic rate of the plant when boric acid is applied. This is because the decrease in photosynthesis promotes the reduction of the intake of atmospheric $\mathrm{CO}_{2}$, thereby reducing the plant internal $\mathrm{CO}_{2}$ rate (Salisbury and Ross, 1992).

This study showed that B application on soil using doses up to $2 \mathrm{~kg} \mathrm{ha}^{-1}$ is economically viable, regarless B source. However, in doses higher than that, borax showed a higher economic gain. Theses results are in accordance with Flores et al. (2017), who observed higher economic gain applying $4 \mathrm{~kg} \mathrm{ha}^{-1}$ of $\mathrm{B}$ in leaves, using only one application of borax applied when flowering started. 


\section{Conclusions}

Regarding the productive yield of common beans, the more soluble source (boric acid) promoted the greatest absorption of B by the culture, resulting in the highest yield of common beans. In this case, the results suggest that the fertilization recommendation for common bean crops grown in an irrigated system under the same soil and climatic conditions as of this study can be reduced by $25 \%$ without losses in yield. Regarding economic viability in function of differential gain, it was possible to identify differences among the economic efficiencies of sources and boron doses evaluated, suggesting the application of $4 \mathrm{~kg} \mathrm{ha}^{-1}$ of borax as the most efficient source. The historical price series, used as a basis to calculate average bean sack prices, has no record of the price that provided a negative differential profit, indicating that boron application would be economically efficient over the past 15 years for the source with the greatest efficiency detected by the data of this study.

\section{Acknowledgement}

The authors are grateful for Foundation for Research Support of the State of Goiás (FAPEG) financial support for the realization and dissemination of this research.

\section{References}

Agrolink. 2017. Quotation history. Retrieved from http://www.agrolink.com.br/cotacoes/historico/ go/feijao-carioca-sc-60kg

Bataglia, O.C., Furlani, A.M.C., Teixeira, J.P.F., Furlani, P.R. 1983. Métodos de análise química de plantas. Instituto Agronômico, Boletim Técnico, Campinas, $48 \mathrm{p}$.
Chen, L.S., Han, S., Qi, Y.P., Yang, L.T. 2012. Boron stresses and tolerance in citrus. Afr. J. Biotechnol. 11, 5961-5969.

Couto Junior, P.A., Silva, A.A., Lana, R.M.Q. 2013. Aplicação de diferentes doses e adubação de micronutrientes via solo na cultura do feijoeiro. Biosci. J. 29, 8-14.

Dechen, A.R., Nachtigall, G.R. 2006. Micronutrientes. In M. S. Fernandes (ed). Nutrição mineral de plantas. Sociedade Brasileira de Ciência do Solo, Viçosa, 432 p.

Dechen, A.R., Nachtigall, G.R. 2007. Elementos requeridos à nutrição de plantas. In: R.F., Novais, V.V.H., Alvarez, N.F., Barros, R.L.F., Fontes, R.B., Cantarutti, J.C.L., Neves (eds). Fertilidade do Solo. Sociedade Brasileira de Ciência do Solo, Viçosa, pp. 92-132.

Embrapa - Empresa Brasileira de Pesquisa Agropecuária. 2012. Informações técnicas para o cultivo do feijoeiro-comum na Região CentralBrasileira: 2012-2014. Embrapa Arroz e Feijão, Santo Antônio de Goiás, 242 p.

Euba Neto, M., Fraga, V.S., Pereira, W.E., Dias, B.O., Souto, J.S. 2014. Níveis críticos de boro para a cultura do girassol em solos com texturas contrastantes. Rev. Caatinga. 27, 100-108.

Fageria, N.K., Stone, L.F., Santos, A.B., Carvalho, M.C.S. 2015. Nutrição mineral do feijoeiro. Embrapa, Brasília, 394 p.

Fao - Food and Agriculture Organization of the United Nations. 2012. Faostat. Retrieved from http://faostat.fao.org/site/567/default.aspx\#ancor

Ferreira, D.F. 2014. Sisvar: a Guide for its Bootstrap procedures in multiple comparisons. Ciênc. Agrotec. 38, 109-112. 
Flores, R.A., Silva, R.G., Cunha, P.P., Damin, V., Abdala, K.O., Arruda, E.M., Rodrigues, R. A. Maranhão, D.D.C. 2017. Economic viability of Phaseolus vulgaris (BRS Estilo) production in irrigated system in a function of application of leaf boron. Acta Agric. Scand. B. 67, 697-704.

Godoy, L.J.V., Santos, T.S., Villas Bôas, R.L., Leite Júnior, J.B. 2008. Relative chlorophyll index and nitrogen status of fertigated coffee plants during the crop season. Rev. Bras. Ciênc. Solo. 32, $217-$ 226.

Lemiska, A., Pauletti, V., Cuquel, F.L., Zawadneak, M.A.C. 2014. Production and fruit quality of strawberry under boron influence. Cienc. Rural. 44, 622-628.

Lima, J.C.P.S., Nascimento, C.W.A., Lima, J.G.C., Lira Junior, M.A. 2007. Critical and toxic boron levels in corn plants and soils of Pernambuco, Brazil. Rev. Bras. Ciênc. Solo. 31, 73-79.

Lima, M.L., Cardoso, F.R, Gaçante, A.H.A., Teixeira, G.C.S., Teixeira, I.R, Alves, S.M.F. 2013. Fontes e doses de boro na qualidade de sementes de feijão-comum e mamona sob consórcio. Rev. Caatinga. 26, 31-38.

Malavolta, E. 2006. Manual de nutrição mineral de plantas. Editora Agronômica Ceres, São Paulo, $631 \mathrm{p}$.

Marschner, H. 2012. Mineral nutrition of higher plants. Academic Press, London, 672 p.

Mattiello, E.M., Ruiz, H.A., Silva, I.R., Barros, N.F., Neves, J.C.L., Behling, M. 2009. Transport of boron in soil and its uptake by eucalypt. Rev. Bras. Ciênc. Solo. 33, 1281-1290.

Noronha, J.F. 1987. Projetos agropecuários \& administração financeira: orçamento e viabilidade econômica. ATLAS, São Paulo, 269 p.
Ouzounidou, G., Paschalidis, C., Petropoulos, D., Koriki, A., Zamanidis, P., Petridis, A. 2013. Interaction of soil moisture and excess of boron and nitrogen on lettuce growth and quality. Hortic. Sci. 40, 119-125.

Papadakis, I.E., Dimassi, K.N., Bosabalidis, A.M., Therios, I., Patakas, A., Giannkoula, A. 2004. Effects of B excess on some physiological and anatomical parameters of "Navelina" orange plants grafted on two rootstocks. Environ. Exp. Bot. 51, 247-257.

Prado, R.M. 2008. Nutrição de plantas. UNESP, São Paulo, 407 p.

Richetti, A., Melo, C.L.P. 2013. Viabilidade econômica da cultura do feijão comum, safra da seca de 2014, em Mato Grosso do Sul. Embrapa, Dourados, $12 \mathrm{p}$.

Sá, A.A., Ernani, P.R. 2016. Boron leaching decreases with increases on soil pH. Rev. Bras. Ciênc Solo. 40, e0150008.

Salisbury, F.B., Ross, C.W. 1992. Plant physiology, $4^{\text {th }}$. ed, Wadsworth Publishing Company, California, pp.362-600.

Silva, D.H. 2007. Boro em mamoeira: aspectos morfológicos e fisiológicos relacionados a deficiência e toxicidade Dissertation, Centro de Energia Nuclear na Agricultura de São Paulo, São Paulo, 103 p.

Simón, I., Días-López, L., Gimeno, V., Nieves, M., Pereira, W.E., Martínez, V., Lidon, V., GarcíaSánchez, F. 2013. Effects of boron excess in nutrient solution on growth, mineral nutrition, and physiological parameters of Jatropha curcas seedlings. J. Plant Soil Sci. 176, 165-174.

Soil Taxonomy. 2006. Keys to soil taxonomy by soil survey staff, 10th ed. United States Department 
of Agriculture Natural Resources Conservation Service, Washington, $341 \mathrm{p}$.

Souza, D.M.G., Lobato, E. 2004. Cerrado: correção do solo e adubação, Embrapa, Planaltina, 416 p.

Souza, H.A.D., Hernandes, A., Romualdo, L.M., Rozane, D.E., Natale, W., Barbosa, J.C. 2011. Folha diagnóstica para avaliação do estado nutricional do feijoeiro. Rev. Bras. Eng. Agríc. Ambient. 15, 1243-1250.

Trautmann, R.R., Lana, M.C., Guimarães, V.F., Gonçalves Jr., A.C., Steiner, F. 2014. Soil water potential and boron fertilization in growth and uptake of the nutrient for the soybean crop. Rev. Bras. Cienc. Solo. 38, 240-251.
Wasaya, A., Shabir, M.S., Hussain, M., Ansar, M., Aziz, A., Hassan, W., Ahmad, I. 2017. Foliar application of zinc and boron improved the productivity and net returns of maize grown under rainfed conditions of Pothwar plateau. J. Soil Sci. Plant Nutr. 17, 33-45.

Yadegari, M. 2016. Effect of micronutrients foliar application and biofertilizeres on essential oils of lemon balm. J. Soil Sci. Plant Nutr. 16, 702-715.

Zhu, H., Zhao, Y., Nan, F., Duan, Y., Bi, R. 2016. Relative influence of soil chemistry and topography on soil available micronutrients by structural equation modeling. J. Soil Sci. Plant Nutr. 16, 1038-1051. 